\title{
Facebook Tools and Digital Learning Achievements in Higher Education
}

\author{
Nitza Davidovitch ${ }^{1} \nsim$ \\ Margarita Belichenko ${ }^{2}$ \\ ${ }^{1,2}$ Multidisciplinary Department, Ariel University, Israel \\ Email:d.nitza@,ariel.ac.il
}

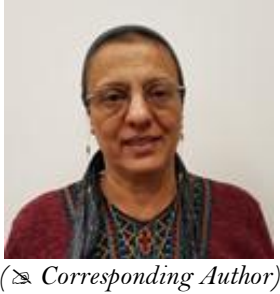

Corresponding Author)

\begin{abstract}
During recent years there has been a significant increase in the usage of technological tools in general, and in academic teaching in particular. Many programs have been developed, including online teaching and online courses at educational institutions. In this paper, we discuss the Facebook social network and its use at the University. The research shows that Facebook groups are used to facilitate communication between students, to foster a positive social climate, to create dialogue and to share learning material among group members. The paper examines students' achievements and their satisfaction with the impact of the Facebook group on the academic course, in order to examine whether the use of Facebook groups in academic courses can improve course quality and students' achievements.
\end{abstract}

Keywords: Facebook, On-line courses, Higher education, Structural analysis, Digital learning.

Citation | Nitza Davidovitch; Margarita Belichenko (2018) Facebook Tools and Digital Learning Achievements in Higher Education. Journal of Education and e-Learning Research, 5(1): 814.

History:

Received: 4 December 2017

Revised: 8 January 2018

Revised: 8 January 2018

Published: 15 January 2018

Licensed: This work is licensed under a Creative Commons Attribution 3.0 License $(\mathrm{cc})$ )

Publisher: Asian Online Journal Publishing Group
Contribution/Acknowledgement: Both authors contributed to the conception and design of the study.

Funding: This study received no specific financial support.

Competing Interests: The authors declare that they have no conflict of interests.

Transparency: The authors confirm that the manuscript is an honest, accurate, and transparent account of the study was reported; that no vital features of the study have been omitted; and that any discrepancies from the features of the study have been omity as planned have been explained.
study

study as planned have been explained.
Ethical: This study follows all ethical practices during writing.

\section{Contents}

1. Introduction 9

2. Method 11

3. Findings

12

4. Conclusion

References. 


\section{Introduction}

It is evident that there is a new generation of students known as members of the "digital and network generation," who are surrounded by information and communication technologies that include Internet, smartphones, and mass media. Course Facebook groups are used to facilitate communications among students, to foster a positive social climate in the classroom, to create dialogue and to engage students, and to serve as a learning tool. The paper examines the level of achievements of students and their satisfaction as part of an educational Facebook group.

The changes created by the technological age have had a great impact on universities. Many students now come to classes equipped with laptops that offer great access to the Internet at any time, including during lectures. These mobile devices support students' active learning and serve as substitutes for traditional classmate, creating a personal learning environment in the classroom and outside. The use of laptops allows students to be connected to learning resources even when they are not at the university, creating a learning continuum independent of time or place. In other words, even at home, students can continue learning continuously. The contribution of online instruction is reflected not only in the effective learning of students, but also provides faculty with a rich and knowledgeable approach to the transfer of lesson content (Barak et al., 2006; Mifsud et al., 2013). It has been shown that lecturers who refer students to real and relevant information during class produce interesting and diverse learning experiences for their students (Mishar - Tal et al., 2012).

\subsection{Problem Statement}

The use of technological tools during class has positive effects, both on the quality of learning and on students' motivation for learning. However, despite the many advantages that technological tools produce, there are also negative effects on students, such as distraction caused by surfing websites that are not related to the lesson, checking and sending e-mail, social networking, and playing attractive games (Kraushaar and Novak, 2010; Gehlen-Baum and Weinberger, 2012).

\subsection{Facebook}

Facebook was created in February 2004 by Mark Zuckerberg at Harvard University. The network was initially limited to students and later became a global phenomenon, accessible by anyone with an e-mail address Facebook has become one of the seven most popular sites in the United States, users around the world (Bosch, 2009).

Facebook is also one of the most popular social networks in in Israel. According to a ComScore survey, penetration of Facebook among Internet users aged 15 and over is $89.8 \%$. This is the second highest penetration rate in the world, after the Philippines. Israel is leads in duration of use, reaching about 10.5 hours a month per user (Comscore.com).

\subsection{Facebook and its Applications at Ariel University}

With the emergence of Facebook groups that do not require members to be "friends" or expose their lives to one another, the option of creating a "study group" with students and lecturers is on the rise, and the effects of of using Facebook groups as an alternative learning management system (LMS) has become increasingly relevant.

Any Facebook user can set up a Facebook group. After the group is established, the group founder can invite other Facebook users to register for the group. Groups can choose to restrict membership to specific individuals or open the group for access by anyone. Unlike other Facebook activity, a closed learning group does not appear in any user's activity records, and is published only among the members of the group (Mishar - Tal et al., 2012).

The main uses of Facebook learning groups include posing questions about homework, test material, exams, and assignments, and sharing summaries uploaded by students (Cohen and Eini, 2012).

As a tool of learning, Facebook has also reached universities. The ability of higher education to utilize social media to advance professional development, expand institutional development, and increase students success is no less than revolutionary. A few decades ago, most students came from society's elite classes, but today, the student population has changed and students come from all levels of the population, increasing cultural diversity among students, and all its implications. In addition, today's students are digital natives: They have grown up into a reality with sophisticated technology, availability and intensive use of mobile and social media. Despite the development of technology and the fact that every student now has a mobile device and a laptop, teaching methods in most academic courses have retained a traditional form. The students' learning environment must be updated to include classroom teaching and home tasks that utilize the capabilities of mobile media and social media (Division, 2015).

Motivation refers to the process in which goal-oriented activities are energetic, directed, and sustained. A student's motivation was found to be a major factor in learning achievements. Other studies have explored basic questions such as how and why some students succeed in the learning process, while other students struggle to develop knowledge and cognitive resources necessary for academic success. Therefore, in designing a new learning environment that makes use of new technologies, the role of motivation must be taken into account. Researchers and educators have focused on new design projects, curriculum reforms, and innovative technological tools to raise motivation (Pintrich, 2003).

\subsection{The Learning Process Model}

The penetration of social networks into everyday life has attracted the interest of many organizations and researchers to explore the influence of social networks on teaching and learning and has triggered efforts to use social networks for teaching and learning purposes. According to a learning process model developed by Biggs and Moore (1993) the learning process contains four key components that influence learning outputs:

1. A well-structured knowledge base: The quality of the knowledge base is assessed by three characteristics: the quantity of knowledge, the quality of the organization of knowledge, and the accessibility of the 
knowledge. Anything that helps the student know more, organize the material in their minds or increases its accessibility, will improve the quality of studenst' knowledge bases.

2. Motivational context: Certain conditions encourage students' intrinsic motivation. . Two key conditions are clear goals and instructions, and a warm, positive climate that the teacher creates.

3. interactions: Learning comprises three main interactions: teacher-student, student-student, and contentstudent, with an emphasis on the essential role of the teacher-student interaction in the teaching process.

4. Active learning.

Another model of interaction analysis was suggested by (Henri, 1991; Stone and Henry, 2003) who distinguished between 4 types of interactions: social, cognitive, procedural, and explanatory.

- Social interaction refers to a dialogue of a friend-like nature: the teacher encourages students to express feelings. Oren and Oren (1999) found that in these forums almost no interaction is created.

- Cognitive interaction entails investigation into the depth of a topic, linking it to other subjects, raising questions, critiquing and analyzing it. Klein and Doran (1999) found this kind of interaction in social network forums: The more involved the student, the more active and the more applied to his learning.

In general, Biggs and Moore's message to the teacher is: Do not do it, let the students do it. Based on this model, the following five research questions were formulated:

1. Do Facebook groups enhance students' knowledge base?

2. Do Facebook groups increase students' motivation for learning and their active participation in the learning process?

3. Do Facebook groups encourage student-student interactions?

4. Do Facebook groups encourage social and cognitive interactions?

5. Do Facebook groups encourage active learning by students?

The results of our study show that Facebook plays a constructive role in all four components of the model, including motivation and climate. Facebook groups contribute to students' motivation for learning, especially in a situation where students and teachers have good communications. In addition, Facebook groups contribute to a positive course climate and to students' motivation for their self-development (Lev et al., 2013). A pioneering study in which Facebook was presented to graduate students as an alternative learning management system found that students expressed satisfaction with the Facebook-based learning method and a desire to use similar study groups in other courses as well.

Findings of a recent study offer evidence of students' positive attitudes and satisfaction with their learning experience using Facebook groups. Most students agreed that the collaborative work on Facebook was interesting, informative, and effective. Positive attitudes toward learning in the Facebook environment were not, however, associated with students' academic achievements on their final test (Arieh and Rimor, 2013).

\subsection{The Impact of Technological Tools in Academic Institutions}

Today, many students come to class with laptops that provide great accessibility to the Internet at any time. These mobile devices support students' active learning and offer a a substitute for traditional study tools: With these devices, students bring with them a personal learning environment to the classroom and outside.The contribution of online instruction is reflected not only in effective student learning, but also enables the faculty to have a knowledgeable approach to the transfer of lesson content (Campbell and Pargas, 2003; Barak et al., 2006; Kraushaar and Novak, 2010; Mifsud et al., 2013) It can be seen that lecturers who refer students to real and relevant information during the lesson produce interesting and broad learning experiences for their students (Mishar - Tal et al., 2012).

Technological tools in and outside class essons have positive effects, both on the quality of learning and on students' motivation for learning, but there are also negative effects on learners, such as distractions caused by browsing websites that are not related to the topic, and engagement in social networking (Kraushaar and Novak, 2010; Gehlen-Baum and Weinberger, 2012).

\subsection{The Teacher's Role in Digital Learning}

Online courses in general and the role of lecturers in online teaching, in particular, are topics of extensive research in institutions of higher education around the world (Dabbagh, 2002; Easton, 2003; Danchak and Huguet, 2004). Teaching and digital learning enable and require changes to traditional teaching methods or looking for new ways to adapt to the the transition from the teacher's role in traditional learning and her role in online learning environments. E-learning is different from traditional teaching in several respects, including in the roles of facilitator and students, models of communication, interactions, and learning flexibility.

Researchers and educators are introducing new insights into online learning. In their opinion, to ensure that the transition to electronic courses is not merely technological, online instruction must be based on constructivist and cooperative approaches, which go beyong presenting information that is passively absorbed by students.

The usage of constructivist theories as a rationale and a fundamental principle of instruction adapted to network technology. The goal is to ensure that students in computerized courses will not function as passive learners who receive the material from the lecturer, but will become active learners who construct knowledge themselves. Students are therefore expected to seek information, create meaningful connections between different content and build new knowledge in the field. In the opinion of these researchers and others, the teacher is the most important component in this process to ensure successful e-learning. It is not the technology itself, but the way it is implemented by the teacher that determines the effectiveness of learning.

A review of the professional literature (Davidovitch et al., 2017) in the field reveals the following key characteristics expected of the teacher-facilitator in digital learning environments:

Conducting a dialogue that includes three features: academic interaction, interaction of cooperation, and interpersonal interaction. The mentor-facilitator's management influences these interactions. 
- Active construction of knowledge, when he role of the teacher changes from the transfer of knowledge to mentor, counselor, and colleague who accompanies and directs the student, assists her, and enables her to construct knowledge. For this purpose, students need active guidance from the teacher, rather than passive guidance.

- Awareness and consideration of students' individual learning needs. Students differ in their needs, learning styles, and quality preferences. Therefore, high-quality e-learning must also be directed to each student's individual needs. It is no longer possible to be satisfied with a general model for everyone, but rather the teacher must provide individualized learning services that support each student's subjective preference profile.

- Creating social learning and encouraging interaction in the course. There is an emphasis on the lecturer's need to improve communication skills with the students in order to create a community of learners. Quick responses to learners' questions increase their confidence and motivation for learning.

\subsection{Nira Hativa's Cognitive-Emotional Model of Learning}

A study based on classroom observations found that the main behaviors of effective teaching were enthusiasm, clarity of explanations, and interactions and positive relationships with students. A model of good teaching and key teaching behaviors (Hativa, 2014) suggests that, in general, a good teacher has teaching capacity in two dimensions:

The cognitive dimension represents the teacher's skills in channeling the material to the students. This dimension consists of three types of teaching behaviors:

Organization of the course and lesson - The student is well placed in the framework of the course and the lesson; he knows at every stage of the course what lessons they have learned so far, what they are learning now and what they will learn in the next stages. Also, lesson time is well spent on learning.

Clarity of the lesson - The teacher clearly explains the course and content of the lesson so that the students can understand and implement their understanding and perform the assignments and homework.

Interest / promotion of concentration and attention, intellectual challenge - The lesson is interesting and strengthens concentration and attention among the students. The teacher manages to keep the students engaged throughout the lesson so that they will be focused.

The emotional-affective dimension represents the teacher's skills in creating a pleasant, positive classroom atmosphere that promotes openness, promotion and a desire for learning. This dimension comprises two types of teaching behaviors:

Respect for the students, a warm and sympathetic attitude, empathy for their difficulties in learning, caring and helping them succeed in learning.

Maintaining positive and beneficial interactions with students, such as encouraging questions, and providing good, useful answers to their questions.

In such circumstances, students are satisfied with the teaching, organization, clarity, interest and challenge of the studies and the lecturer's approach is favorable to them. This is equally applicable in different content domains such as engineering and the humanities. To be perceived by students as an outstanding teacher, the teacher must excel in creating clarity, organizing the lesson, and creating a positive classroom atmosphere. Outstanding teaching has a unique and personal aspect: Outstanding teachers are like artists who know how to help their students grow and develop with great skill. Good teaching involves a number of factors that interact with one another and affect student learning effectively (Division, 2015).

In digital teaching, we find similar principles. Students express satisfaction with two main aspects of the digital means at their disposal: the cognitive dimension, which includes organization, clarity, interest and challenge, and the emotional dimension, which represents atmosphere, student encouragement, and positive classroom interactions. The research hypothesis is that there will be a positive correlation between achievements and satisfaction of students who participate in an educational Facebook group.

\section{Method}

The sample included 150 students studying at Ariel University in Samaria, between age 20 and 30, enrolled in BA programs.

Research tools

-We developed an online questionnaire that examines the relationship between participation in an educational Facebook group and students' achievements and satisfactions. The questionnaire examines two main issues: the first is the effectiveness of the group and the student's achievements (cognitive). (example item: Do collaborative Facebook groups allow students to be involved in all stages of learning in the course?). The second topic examined satisfaction and atmosphere among students (emotional aspect). (Example item: Do Facebook collaborative groups create a positive atmosphere that fosters openness among students and a desire for learning?).

\subsection{Procedure}

Participants were sampled on a voluntary basis and recruited throughout Ariel University campus. Participants were informed that participation in the study was not mandatory and they were permitted to terminate their participation at any stage of the study if they felt that their privacy was violated. Participants completed a consent form before receiving a questionnaire, confirming that they were participants of their own free will. The questionnaire was distributed throughout the university at convenient times for participants. A series of demographic questions was followed by a questionnaire on satisfaction with the emotional and cognitive aspects of their Facebook groups. 


\subsection{Analysis}

Dependent variable: level of achievement and satisfaction.

Independent variable: Participation in an educational Facebook group

Based on the data transferred to the statistical analysis, descriptive statistics were presented. Various analyses were conducted on the variables: Facebook group use for learning purposes, level of achievements, and level of satisfaction. To rule out alternative explanations, gender differences, differences between academic years, and other differences were also examined.

\section{Findings}

\begin{tabular}{|c|c|c|c|}
\hline Variable & & $\mathbf{N}$ & $\%$ \\
\hline \multirow[t]{2}{*}{ Sex } & Male & 56 & 37.3 \\
\hline & Female & 94 & 62.7 \\
\hline \multirow[t]{3}{*}{ Family status } & Single & 92 & 61.7 \\
\hline & Married & 51 & 34.2 \\
\hline & Divorcee & 7 & 4.1 \\
\hline \multirow[t]{3}{*}{ Religion } & Secular & 45 & 30.2 \\
\hline & Traditional & 19 & 12.8 \\
\hline & Religious & 85 & 57 \\
\hline \multirow[t]{5}{*}{ Year of studies } & A & 35 & 23.3 \\
\hline & $\mathrm{B}$ & 31 & 20.7 \\
\hline & $\mathrm{C}$ & 50 & 33.3 \\
\hline & $\mathrm{D}$ & 17 & 11.3 \\
\hline & Other & 17 & 11.3 \\
\hline
\end{tabular}

Source: research findings

Table-2. Descriptive statistical data of the research variables

\begin{tabular}{l|l|l|l|l}
\hline Variable & $\mathbf{N}$ & Range & Average & Standard deviation \\
\hline Age & 150 & $35-18$ & 24.44 & 2.78 \\
\hline Aspiration & 150 & $4-1$ & 2.72 & 0.933 \\
\hline Satisfaction & 150 & $4-1$ & 2.72 & 0.937 \\
\hline Source: research findings
\end{tabular}

To test the hypothesis regarding a positive correlation between the level of achievement of Facebook group members and their satisfaction, a Pearson test was conducted. A strong positive correlation was found $(r p=0.863 p$ $<.01)$, indicating that students who were more satisfied with the Facebook group also had higher achievements in the course and vice versa.

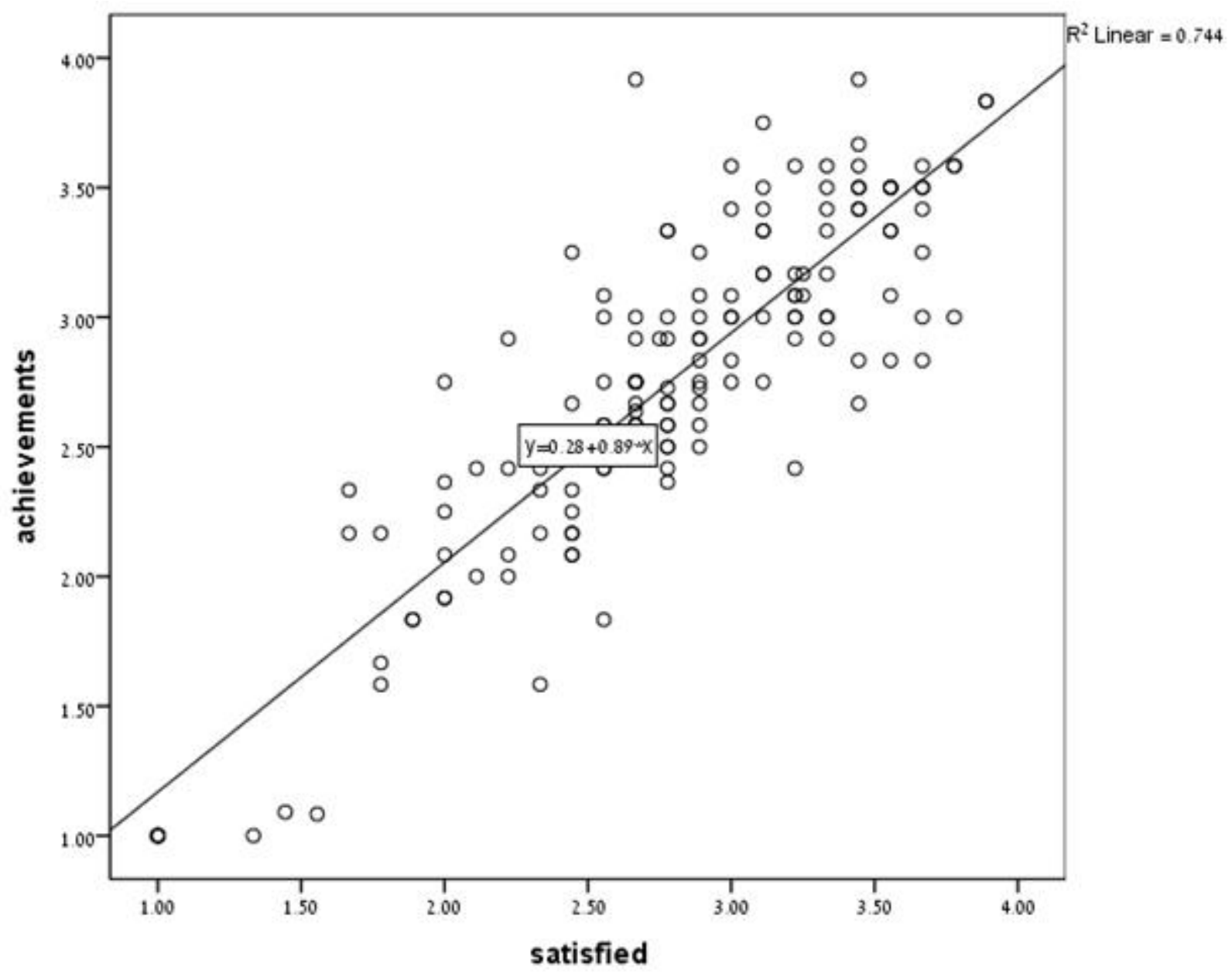

Figure-1. Pearson correlations between achievement and satisfaction among Facebook group members. Source: Research findings 
In conclusion, the present study examined the relationship between success and achievements of students at Ariel University, and their satisfaction with the contribution of a collaborative educational Facebook group. This digital process can be said to have significantly contributed to the students' success and satisfaction, and the Facebook group can certainly serve as an additional tool to supplement traditional frontal instruction. Therefore, the research's recommendation is to integrate Facebook groups into academic courses, to facilitate the transition of academic material beyond academic walls, extends study hours, strengthen the connection between students, and create a comfortable learning atmosphere.

\section{Conclusion}

The present paper examined satisfaction among students taking part in a collaborative Facebook learning group and how collaborative Facebook groups influence students' achievements. The findings suggest that there is a strong correlation between these variables, which may help raise awareness of the potential of using the Facebook group platform for educational purposes.

\subsection{Research Contributions}

The current study may help raise awareness of the potential use of Facebook groups for educational purposes. Using the Facebook groups for study purposes expands students' study hours beyond the hours of frontal study in the classroom, and takes the study material out of the university. Moreover, the use of collaborative Facebook groups may enhance students' achievements as a result of positive interactions among group members, including mutual assistance, sharing of educational materials, and other learning-related activities. To overcome the limitations of the study, additional studies should explore this issue with an equal number of men and women.

The Facebook network has great potential that expands the hours of study beyond the frontal hours at University, yet this advantage may be offset by the loss of a face-to-face learning experience. Does technology help the social aspects of frontal teaching? Is there any point in frontal teaching? Is this a tool still relevant for our times? What is the image of the classroom or of the Open University today? Do lecturers make effective use of the digital platforms at their disposal? All these questions are necessary in order to identify the lecturers' role in the learning process and whether they will disappear in the future in which teaching becomes digital.

Confirming the research hypothesis, a positive correlation was found between Facebook users' level of achievement and their satisfaction. The findings of the study can be explained on the basis of Arieh and Rimor (2013) study, which reports students' positive attitudes and satisfaction with their learning experience on Facebook. Notably, participation in a Facebook group allows students to examine the material at home and bring additional knowledge beyond the hours of frontal study. Moreover, students can help each other clarify a subject or discover new knowledge, correct each other's errors, and offer comments. The contribution of the Facebook network should also be examined using additional means and variables that potentially affect its contribution to higher education.

\section{References}

Arieh, P. and R. Rimor, 2013. A play in English hosted on Facebook: An examination of the achievements and attitudes of students regarding the study of a play in English in the Facebook environment. The Chais Conference on Learning Technologies Research, 2013: The Person Who Studied in the Technological Era: Eshet-Alkalai, A. Caspi, S. Eden, N. Geri, Y. Kalman, Y. Yair (eds.), Raanana. pp: 197.

Barak, M., A. Lipson and S. Lerman, 2006. Wireless laptops as means for promoting active learning in large lecture halls. Journal of Research on Technology in Education, 38(3): 245-263. View at Google Scholar | View at Publisher

Biggs, J.B. and P.J. Moore, 1993. The process of learning. 3rd Edn., Sydney: Prentice Hall.

Bosch, T.E., 2009. Using online social networking for teaching and learning: Facebook use at the University of Cape Town. Communication: South African Journal for Communication Theory and Research, 35(2): 185-200. View at Google Scholar $\mid$ View at Publisher

Campbell, A.B. and R.P. Pargas, 2003. Laptops in the classroom. ACM SIGCSE Bulletin, 35(1): 98-102. View at Google Scholar |View at Publisher

Cohen and L. Eini, 2012. Patterns of use of Facebook among youth and attachment to educational processes. The Chais Conference for Learning Technology Research 2012: The Person Who Studied in the Technological Era", Eshet-Alkalai, A. Caspi, S. Eden, N. Gerry, Y. Yair, Y. Kalman, 158.

Dabbagh, N., 2002. Using a web-based course management tool to support face-to-face instruction. Technology Source. Retrieved from http://technologysource.org/article/using_a_webbased_course_management_tool_to_support_facetoface_instruction.

Danchak, M.M. and M.P. Huguet, 2004. Designing for the changing role of the instructor in blended learning. IEEE Transactions on Professional Communication, 47(3): 200-2 10. View at Google Scholar | View at Publisher

Davidovitch, N., M. Belichenko and Y. Kravchenko, 2017. Digital learning characteristics and principles of information resources knowledge structuring. European Journal of Educational Research, 6(3): 261-267. View at Publisher

Division, N., 2015. Why and how to integrate contemporary technologies into academic teaching? Tel Aviv University, 6: 1-1 1.

Easton, S.S., 2003. Clarifying the instructor's role in online distance learning. Communication Education, 52(2): 87-105. View at Google Scholar View at Publisher

Gehlen-Baum, V. and A. Weinberger, 2012. Notebook or facebook? How students actually use mobile devices in large lectures. In: A. Ravenscroft, S. Lindstaedt, C. D. Kloos, \& D. Hernández-Leo (Eds.), 21 st century learning for 21 st century skills. Berlin Heidelberg: Springer-Verlag, 7563: 103-1 12.

Hativa, N., 2014. What does the research say about good teaching and the excellent teacher? Hora'ah Ba'akademya, 4: 43-59.

Henri, F., 1991. Computer conferencing and content analysis. In: Collaborative Learning Through Computer Conferencing, Kay, A., R., Ed., Berlin: Springer Verlag.

Klein, J.D. and M.S. Doran, 1999. Implementing individual and small group learning structures with a computer simulation. Educational Technology Research and Development, 47(1): 97-109. View at Google Scholar | View at Publisher

Kraushaar, J.M. and D.C. Novak, 2010. Examining the effects of student multitasking with laptops during the lecture. Journal of Information Systems Education, 21(2): 241-251. View at Google Scholar

Lev, Y., N. Ne'eman and C. Amit, 2013. The facebook contribution for teaching in academic courses (Poster). The Chais Conference on Learning Technologies Research 2013: The Person Who Studied in the Technological Era. Eshet-Alkalai, A. Caspi, S. Eden, N. Geri, Y. Kelman, Y. Yair (Eds.), 275.

Mifsud, L., A. I., A.I. Mørch and S. Lieberg, 2013. An analysis of teacher-defined activities with mobile technologies: Predecessor and successor tool use in the classroom. Learning, Media and Technology, 38(1): 41-56. View at Google Scholar $\mid$ View at Publisher

Mishar - Tal, H., G. Kortz and E. Pieterse, 2012. Facebook groups as LMS: A case study. International Review of Research in Open and Distributed Learning, 13(4): 33-48. View at Google Scholar | View at Publisher

Oren, Z. and E. Oren, 1999. Grouper: A dynamic clustering interface to web search results. Computer Networks, 31(11-16): 1361-1374. View at Google Scholar | View at Publisher 
Pintrich, P.R., 2003. A motivational science perspective on the role of student motivation in learning and teaching contexts. Journal of Educational Psychology, 95(4): 667-686. View at Google Scholar $\mid$ View at Publisher

Stone, R.W. and J.W. Henry, 2003. The roles of computer self-efficacy and outcome expectancy in influencing the computer end-user's organizational commitment. Journal of End User Computing, 15(1): 38-53. View at Publisher 